\title{
Elementary lesions in dermatological semiology: literature review ${ }^{*}$
}

\author{
Renata Nahas Cardili ${ }^{1}$
}

\author{
Ana Maria Roselino ${ }^{1}$
}

DOI: http://dx.doi.org/10.1590/abd1806-4841.20164931

\begin{abstract}
Discrepancies in the terminology of elementary lesions persist when texts from Dermatology and Semiology books are compared, which can cause some confusion in both the teaching of undergraduate medical students and the learning acquired by professionals in the field. This review aims to compare and clarify the differences in the description of elementary lesions by many authors, used as references for specialists in dermatology.
\end{abstract}

Keywords: Dermatology; Review; Teaching; Terminology

\section{INTRODUCTION}

As regards elementary lesions, used in the teaching of semiology within the Dermatology course, historically, two semantic models were initially described: the Essentialist model, proposed by Robert Willan (1757-1812), followed by Thomas Bateman at the end of the eighteenth century, and the Nominalist model, proposed by Ferdinand Hebra (1816-1880) in the nineteenth century.,

The Essentialist model considers the description of the lesion, taking into consideration its morphological characteristics, such as elevation, consistency, size, and depth, as well as its clinical evolution, that is, the transformation of the lesion in its lifespan and not only the description of the lesion at the exact moment in which it is observed. ${ }^{3}$ This model was accepted and followed by L. T. Biett (França), in which such renowned French authors as Cazenave, Rayer (1793-1867), Darier (1856-1936), and Robert Degos (1904-1987) were loyal to the "Willianist" model until the end of the twentieth century, and it is still used as a references even today. ${ }^{4-7}$

By contrast, in the Nominalist model, Hebra excluded the morphological evolution of the elementary lesion and objectively considered a clear meaning referent to the terminology of known criteria found in the lesion upon observation ("status praesens"). ${ }^{2.3}$ Other modifications carried out by Hebra include: the inclusion of the term 'secondary lesions', the denomination of the lesions according to size (comparing them with lentils and walnuts, for example), as well as the anatomic detection and distribution of the lesions. This model was improved by Kaposi and disclosed throughout Europe at the end of the nineteenth century, mainly through the
Vienna School of Dermatology and later spread to the United States of America (USA), remaining even today as a reference in the majority of Dermatology textbooks in English. ${ }^{8,9}$

The definition of the terminology of elementary lesions, used in the teaching of semiology in Dermatology courses, should be based on descriptive criteria accepted and approved by the majority of authors, aimed at achieving an overall consensus. However, the absence of an agreement among the many authors about the description of these lesions can generate differences in the chapters on dermatological semiology, used as study references and, consequently, doubts in the description of the physical exam.

\section{AIM}

Compare the description and analyze possible divergences in the semantic terminology of elementary lesions in textbooks used by medical students and professionals in the field of Dermatology.

\section{METHODS}

Seven reference books in basic Dermatology were consulted, contemplating four basic authors: Azulay, Bechelli-Curban, Sampaio-Rivitti, and Belda Jr W et al., as well as three authors from international medical literature: Bolognia JL et al., Fitzpatrick et al., and Rook A. ${ }^{10-16}$ The descriptions of elementary lesions within these authors' works were compared, searching for similarities and differences in terminology.

Received on 16.07.2015

Approved by the Advisory Board and accepted for publication on 10.08.2015

* Work conducted in the Dermatology Division of the Ribeirão Preto School of Medicine, Universidade de São Paulo (FMRP-USP), Ribeirão Preto, SP, Brazil. Financial Support: FAEPA (Teaching, Research, and Assistance Support Foundation).

Conflict of Interest: None.

1 Universidade de São Paulo (USP) - Ribeirão Preto, Ribeirão Preto, SP, Brazil. 


\section{RESULTS}

The authors consulted in this study agreed on the description of the majority of dermatological lesions, especially regarding lesions considered to have a liquid content and regarding the lesions with tissue loss. However, discrepancies in terminology, described as macule, papule, nodule, tubercle, and plaque were observed and illustrated in charts 1 to 5 , respectively.

\section{DISCUSSION}

Discrepancies regarding the nomenclature of elementary lesions were observed among all of the authors reviewed in this study.

As regards the term "macule", the differences are linked to the size. Most of the authors consulted in this study considered any size, while only Bolognia et al. ${ }^{14}$ and Fitzpatrick et al. ${ }^{15}$ defined a limit of between $1.0 \mathrm{~cm}$ and $0.5 \mathrm{~cm}$, respectively, though they do cite

Chart 1: Comparison of terminology referent to MACULE among the consulted Dermatology textbooks

Azulay RD; Azulay DR, Abulafia-Azulay L; Dermatologia, 6a-Ed., 2013.

Bechelli-Curban; Compêndio de Dermatologia, 6 6-Ed., 1988.

Belda Jr W; Di Chiacchio N; Criado PR; Tratado de Dermatologia, 2a- Ed., 2014.

Bolognia JL; Jorizzo J; Rapini RP; Dermatology, 2nd Ed., 2008.

Fitzpatrick et al., Dermatology in General Medicine, 7thEd., 2013.

Rook A et al.; Textbook of Dermatology, 8th - Ed., 2010.

Sampaio e Rivitti; Manual de Dermatologia,

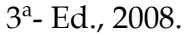

Macule or spot: any and all changes in skin color, no ridges, regardless of nature, cause, or mechanism. Do not cite size.

Macule or spot: change in skin color, no ridges or thickening, varied sizes: lenticular, nummular, plaque and large plaque.

Macule or spot: modifications in skin color, no change in skin ridge or consistency. Can be of two types: pigmentary or blood vessel. Do not cite size.

Small, flat, non-palpable lesion. Prefer to consider the size up to $1.0 \mathrm{~cm}$. Cite that some authors limit the size to $0.5 \mathrm{~cm}$, others to $1.0 \mathrm{~cm}$, and others to any size. Consider "patch" as a macule of greater than $1.0 \mathrm{~cm}$.

Flat, non-palpable lesion, at the same level as the surface around it, with change in color. Consider "patch" lesion similar to macule, but greater than $0.5 \mathrm{~cm}$

Circumscribed change in skin color. Do not mention size.

Change in skin color, no ridges or depressions. Includes blood vessel or pigmentary spots. Do not cite size.

\section{ChART 2: Comparison of terminology referent to PAPULE among the consulted Dermatology textbooks}

Azulay RD; Azulay DR, Abulafia-Azulay L; Dermatologia,6a - Ed., 2013.

Bechelli-Curban; Compêndio de Dermatologia, 6 ${ }^{\text {a-Ed., }} 1988$.

Belda Jr W; Di Chiacchio N; Criado PR; Tratado de Dermatologia, 2a - Ed., 2014.

Bolognia JL; Jorizzo J; Rapini RP; Dermatology, 2ndEd., 2008.

Fitzpatrick's et al.; Dermatology in General Medicine 7th Ed., 2013.

Rook A et al.; Textbook of Dermatology, 8th Ed., 2010.

Sampaio e Rivitti; Manual de Dermatologia, 3 - Ed., 2008.
Efflorescence of hard consistency, surface, measuring $0.5 \mathrm{~cm}$. Causes certain elevation of the skin and, upon involution, does not leave a scar. Upon palpation, there is no significant dermal representation, as the changes are limited to the papillary dermis (contrary to tubercle).

Solid circumscribed elevation of up to $0.5 \mathrm{~cm}$ (varying from punctiform to lenticular); dissemination in disc: nummular or plaque (papulous or placard plaque)

Circumscribed lesion, less than $1.0 \mathrm{~cm}$, elevated, with ridges in relation to the adjacent planes, and flat surface, epidermal, dermal, and mixed.

Palpable lesion, small, circumscribed, surface, elevated, less than $1.0 \mathrm{~cm}$. Cited that some authors consider the size of up to $0.5 \mathrm{~cm}$.

Solid lesions, elevated, up to $0.5 \mathrm{~cm}$.

Palpable lesion, circumscribed, up to $0.5 \mathrm{~cm}$.

Solid lesion, elevated, circumscribed, up to $1.0 \mathrm{~cm}$, by epidermal, dermal, or mixed pathological process. 
CHART 3: Comparison of terminology referent to TUBERCLE among the consulted Dermatology textbooks

Azulay RD; Azulay DR, Abulafia-Azulay L;

Dermatologia, 6a- Ed., 2013.

Bechelli-Curban; Compêndio de Dermatologia, 6a-Ed., 1988.

Belda Jr W; Di Chiacchio N; Criado PR;

Tratado de Dermatologia, 2a- Ed., 2014.

Bolognia JL; Jorizzo J; Rapini RP; Dermatology, 2nd Ed., 2008.

Fitzpatrick's et al.; Dermatology in General Medicine 7th Ed., 2013.

Rook A et al.; Textbook of Dermatology, 8th Ed.,2010.

Sampaio e Rivitti; Manual de Dermatologia, 3a- Ed., 2008.
Efflorescence of hard consistency, elevated, generally measuring more than $0.5 \mathrm{~cm}$. Results from the infiltration of mesenchymal cells to the level of the entire dermis, and consequently, often leaving scars upon involution.

Solid circumscribed elevation, greater than $0.5 \mathrm{~cm}$, located in the dermis (different from the nodule, which is in the subcutaneous tissue)

Do not cite term.

Do not cite term.

Do not cite term.

Do not cite term.

Consider the term to be outdated but characterize it as a papule or nodule that evolves with a scar.

\section{CHART 4: Comparison of terminology referent to PLAQUE among the consulted Dermatology textbooks}

Azulay RD; Azulay DR, Abulafia-Azulay L; Dermatologia, 6a - Ed., 2013.

Bechelli-Curban; Compêndio de Dermatologia, 6 ${ }^{\text {a }}$-Ed., 1988.

Belda Jr W; Di Chiacchio N; Criado PR;

Tratado de Dermatologia, 2a - Ed., 2014.

Bolognia JL; Jorizzo J; Rapini RP; Dermatology, 2ndEd., 2008.

Fitzpatrick's et al.; Dermatology in General Medicine 7th Ed., 2013.

Rook A et al.; Textbook of Dermatology, 8th Ed., 2010.

Sampaio e Rivitti; Manual de Dermatologia, 3a- Ed., 2008.
Lesion, elevates in plateau, which arises from the convergence of numerous papules.

Do not cite the term in an isolated manner. Cite papulous or placard plaque upon describing coalescence of papules.

Lesion generally elevated and flat on the surface, greater than $1.0 \mathrm{~cm}$. Can begin with keratinization, maceration, peeling, or crusting on the surface. Consider the term papulous plaque as the convergence of papules, and the term maculous plaque as the convergence of macules.

Palpable lesion, elevated, greater than $1.0 \mathrm{~cm}$.

Solid elevation, which occupies a surface area that is relatively large when compared to its height, and with a diameter of greater than $0.5 \mathrm{~cm}$

Elevated area of the skin, usually with a size of greater than or equal to $2.0 \mathrm{~cm}$. Can be constituted by coalescence of papules or nodules. The term small plaque can be used for lesions of $0.5 \mathrm{~cm}$ to $2.0 \mathrm{~cm}$.

Do not cite term in an isolated manner. possible differences. When a "macule" is described (synonym for "spot"), one must describe the size and topography. The definition of the spot affects changes only in skin color, whether of blood vessel origin or of pigmentary origin. How should one describe a hypochromic or hyperchromic spot outside of the size range between $0.5 \mathrm{~cm}$ and $1.0 \mathrm{~cm}$ ? Prior literature suggests the use of the following sizes for spots: punctiform, lenticular (size of a lentil), nummular (size of a coin), in plaque (size of one's palm), and in large plaque (larger than a plaque). ${ }^{17}$

As regards the term "papule", all of the authors agreed on the description as a solid, raised lesion, although there were differences in size in which some authors, such as Azulay et al. ${ }^{10}$, Bechelli-Curban ${ }^{11}$, Fitzpatrick et al. ${ }^{15}$, and Rook ${ }^{16}$ considered a size of up to $0.5 \mathrm{~cm}$, while Belda Jr, W et al. ${ }^{13}$, Bolognia et al. ${ }^{14}$, and Sampaio-Rivit$\mathrm{ti}^{12}$ considered up to $1.0 \mathrm{~cm}$. Also as regards the term "papule", Azulay et al. ${ }^{10}$ reported that the lesion described as a "papule" evolves without a scar. These authors also consider that, upon palpation, this lesion has no dermal significance. Hence, as a consensus, they suggest the description of "papule" as a lesion with a solid content with up to $1.0 \mathrm{~cm}$ in diameter. When the lesion is larger than $1.0 \mathrm{~cm}$, 
CharT 5: Comparison of terminology referent to NODULE among the consulted Dermatology textbooks

\begin{tabular}{|c|c|}
\hline $\begin{array}{l}\text { Azulay RD; Azulay DR, Abulafia-Azulay } \\
\text { L; Dermatologia, 6 6- Ed., } 2013 .\end{array}$ & $\begin{array}{l}\text { Efflorescence of hardened consistency, of varying dimensions, sometimes } \\
\text { visible by simple inspection, other times recognized by palpation, resulting } \\
\text { from the increase in the number of cells in the dermis, generally deep and/or } \\
\text { at the level of the subcutaneous tissue. }\end{array}$ \\
\hline $\begin{array}{l}\text { Bechelli-Curban; Compêndio de Dermat- } \\
\text { ologia, 6 } 6^{\text {a-Ed., }} 1988 .\end{array}$ & $\begin{array}{l}\text { Solid formation in the subcutaneous tissue, many times more palpable than } \\
\text { visible. Size varies from that of a pea to that of a hazelnut (larger would be } \\
\text { called nodular plaque). Variable consistency and color. }\end{array}$ \\
\hline $\begin{array}{l}\text { Belda Jr W; Di Chiacchio N; Criado PR; } \\
\text { Tratado de Dermatologia, 2a- Ed., } 2014 .\end{array}$ & $\begin{array}{l}\text { Solid cell infiltrate, circumscribed, persistent, dermal (when elevated) and } \\
\text { hypodermal (when more palpable than visible), generally quite limited, from } \\
1.0 \text { to } 3.0 \mathrm{~cm} \text {. }\end{array}$ \\
\hline $\begin{array}{l}\text { Bolognia JL; Jorizzo J; Rapini RP; Derma- } \\
\text { tology, 2nd Ed., } 2008 .\end{array}$ & $\begin{array}{l}\text { Firm lesion (hardened), thicker and deeper than the papule or plaque. If sub- } \\
\text { cutaneous, it may not elevate the skin. }\end{array}$ \\
\hline $\begin{array}{l}\text { Fitzpatrick's et al.; Dermatology in Gen- } \\
\text { eral Medicine 7thEd., } 2013 .\end{array}$ & $\begin{array}{l}\text { Solid lesion, palpable, round or elliptic, greater than } 0.5 \mathrm{~cm} \text {. Divides into: } \\
\text { epidermal; epidermal/dermal; dermal; dermal/subepidermal; subcutaneous. }\end{array}$ \\
\hline $\begin{array}{l}\text { Rook A et al.; Textbook of Dermatology, } 8 \\
\text { th Ed., } 2010 \text {. }\end{array}$ & $\begin{array}{l}\text { Solid mass on the skin }>0.5 \mathrm{~cm} \text {, observed as an elevation or can be palpated. } \\
\text { Can involve the epidermis or the dermis; dermis and subcutaneous tissue; or } \\
\text { only the subcutaneous tissue. }\end{array}$ \\
\hline $\begin{array}{l}\text { Sampaio e Rivitti; Manual de Dermatolo- } \\
\text { gia, 3ª - Ed., } 2008 .\end{array}$ & $\begin{array}{l}\text { Solid formation, circumscribed, salient or not, of } 1.0 \text { to } 3.0 \mathrm{~cm} \text {. Pathological } \\
\text { process located in the epidermis-dermis and/or subcutaneous tissue. Greater } \\
\text { than } 3.0 \mathrm{~cm} \text { would be called nodular plaque. }\end{array}$ \\
\hline
\end{tabular}

the term "tubercle" is preferred. These leasions can also be considered punctiform and, when coalesced, form a plaque. The characteristics of color, whether shiny or not, whether flat or semi-round, whether covered by blisters or crusts, or by scaling, can be added to the description. ${ }^{17}$

As regards the term "tubercle", Belda Jr, et al. ${ }^{13}$, Bolognia et al. ${ }^{14}$, and Rook ${ }^{16}$ do not use this term, while Sampaio-Rivitti ${ }^{12}$ use it, but consider the term to be outdated. Authors such as Azulay et al. and Bechelli-Curban consider this terminology and classify it as a solid lesion of greater than $0.5 \mathrm{~cm}$, that is, what many other authors call a 'papule' or 'nodule'. 10,11 Azulay et al. add that the lesion results from infiltration in all dermises and generally involutes with a scar. ${ }^{10}$ Thus, it can be considered that a tubercle is a solid lesion that is greater than $1.0 \mathrm{~cm}$ in size. The tubercle is different from a nodule in that the former is located above the tangential plane of the skin, while the latter is more visible than palpable, with the epidermis almost completely covering the wound area, without considering possible signs of inflammation. ${ }^{17}$ Bechelli-Curban describe the nodule as a process of the subcutaneous tissue. ${ }^{11}$ Even if considered to be outdated (Sampaio-Rivitti), the tubercle is a nodule. ${ }^{12}$

As regards the term "plaque", differences were also found among the authors, in which Bechelli-Curban and Sampaio-Rivitti do not cite the term in an isolated manner, but rather as a reference to the size of other elementary lesions, whereas the other authors consider the term 'plaque' for flat lesions or raised lesions of greater than 1.0 or $2.0 \mathrm{~cm} .11,12$ Therefore, the definition of 'plaque', according to the authors, must be added if the plaque is flat or raised. These terms are used to explain the definition of the elementary lesion, but are not considered to be medical terminology - flat or raised lesions.
By contrast, Azulay et al., as well as Bechelli-Curban, consider the term to be a raised plateau lesion, which arises from the convergence of many papules. . $^{10,11}$

Finally, the terminology in which the greatest differences in meaning were observed was of the elementary lesions described as a 'nodule'. Each author described this with some similarities, yet with differences regarding the size and depth of the lesion. Most authors consulted in this study described the 'nodule' with variations in its depth, which can be epidermal and/or dermal and/ or subcutaneous, which results in differences in the physical exam as regards the predominance of visibility or palpation of the lesion. Bechelli-Curban described the term 'nodule' as a lesion located in the subcutaneous tissue. ${ }^{11}$ Many differences were also observed as regards size, in which some authors, such as Bolognia et al. ${ }^{14}$, did not cite this term; others, such as Azulay et al. ${ }^{10}$, consider the lesion with variable dimensions; others, such as Bechelli-Curban ${ }^{10}$, consider the term as being the size of a pea or a hazelnut; others, such as Fitzpatrick et al. ${ }^{15}$ and Rook et al. ${ }^{16}$, consider this term when it is larger than $0.5 \mathrm{~cm}$; while others, such as Sampaio-Rivitti ${ }^{12}$ and Belda Jr et al. ${ }^{13}$, consider this term when the lesion is between 1.0 and $3.0 \mathrm{~cm}$. Authors claim that the nodule should be described as visible or palpable. The characteristics of the skin that surround it are described, as is the consistency, whether it is adherent or not to deep planes. The description of the nodule is quite similar to the description of lymph nodes. Thus, the size of the nodule can be described when comparing it to a pea, a lentil, a hazelnut, or a quail egg, or it can be measured approximately in centimeters. When the nodule is not specific to palpation, one can employ the name "nodular plaque". ${ }^{17}$ The consensus for the proper semantics of dermatological 
terminology thus becomes rather complicated, taking into account the existence of the two models described above, the Essentialist and the Nominalist, both used in many countries. ${ }^{3,8,18}$

Through these initial models, renowned authors of more recent books place their modifications and individual preferences in textbooks, resulting in slight discrepancies in the description of some elementary lesions, which makes teaching difficult for professionals in the field of Dermatology, and hinders the learning process of those in training.

It can be concluded from this review that the description reported by many authors must be considered, and that such differences related to the dermatological nomenclature must be accepted, it being up to the teaching institution and/or professional in the field to use the reference of their choice. In addition, the students and residents must be informed about the didactic preference and for what reasons. Moreover, the institution should call their attention to the existence of these possible differences within the many reference textbooks on cutaneous semiology, and even among the professionals of the same teaching institution, in an attempt to avoid conflicts and doubts in the description of elementary lesions.

\section{ACKNOWLEDGEMENTS}

To the faculty, assistant doctors, and residentes who took the seminar "Elementary Lesions" in the Medical Residence Program in Dermatology at the Ribeirão Preto Clinical Hospital, Ribeirão Preto School of Medicine, University of São Paulo.

\section{REFERENCES}

1. Bateman T. A practical synopsis of cutaneous diseases according to the arrangement of Dr Willan, exhibiting a concise view of the diagnostic symptoms and the method of treatment. Philadelphia: Collins \& Croft; 1818.

2. Hebra $F$. Traité des maladies de la peau comprenant les exanthème saigüs. Paris: G. Masson; 1872-8.

3. Scadding JG. Essentialism and nominalism in medicine: logic of diagnosis in disease terminology. Lancet. 1996;348:594-6.

4. Cazenave A, Schedel HE. Abrég é pratique des maladies de la peau d'aprés les auteurs les plus estimés et surtout d'aprés les documents puisés dans les leçons cliniques de M. le docteur L.T. Biett, médecin de L'Hopital Saint-Louis. Paris: Bechet Jeune; 1838.

5. Rayer P. Traité théorique et pratique des maladies de la peau. Paris: JB Bailliére; 1835.

6. Darier J. Précis de Dermatologie. Paris: Masson; 1923.

7. Degos R. Dermatologie. Paris: Flammarion; 1953.

8. Kaposi M. Pathologie e ttraitement des maladies de la peau. Paris: G. Masson; 1891.

9. Vázquez-López F, Coto P, Gotor ML, Gomes-Diaz S, Pérez-Oliva N. Semiología cutánea: perspectiva histórica de la evolución de la terminología básica en España. Actas Dermosifiliogr. 2006;97:153-8.

10. Azulay RD, Azulay DR, Abulafia-Azulay L. Dermatologia. 6.ed. Rio de Janeiro: Guanabara Koogan; 2013.

11. Bechelli LM, Curban G. Compêndio de Dermatologia. 6. ed. São Paulo: Atheneu; 1988.

12. Sampaio SAP, Rivitti EA. Manual de Dermatologia. 3. ed. São Paulo: Artes Médicas; 2008.

13. Belda Jr W, Di Chiacchio N, Criado PR. Tratado de Dermatologia. 2. ed. São Paulo: Atheneu; 2014.

14. Bolognia JL, Jorizzo J, Rapini RP, editors. Dermatology. 2nd ed. St. Louis, MO: Mosby-Elsevier; 2008.

15. Goldsmith LA, Katz SI, Gilchrest BA, Paller AS, Leffell DJ, Wolff K. Fitzpatrick's Dermatology in General Medicine. 7th ed. New York: Mc Graw Hill Medical; 2013.

16. Burns T, Breathnach S, Cox N, Griffiths C. Rook's Textbook of Dermatology. 8th ed. Oxford: Blackwell Science; 2010.

17. Roselino AMF, Simões B, Pereira FA, de Paula FJA, Vanucchi H, Martinez JAB, et al. Exame físico geral. Semiologia Geral e especializada. Rio de Janeiro: Guanabara Koogan; 2012.

18. Munevar LPL. Trabajo de grado presentado para optar al título de dermatologa. Universidad Nacional de Colombia: Facultad de Medicina Bogotá; 2011.

\author{
MAILING ADDRESS: \\ Renata Nahas Cardili \\ Hospital das Clínicas de Ribeirão Preto \\ Divisão de Dermatologia - $4^{\circ}$. Andar \\ Av. Bandeirantes 3900 \\ 14049-900 Ribeirão Preto, SP \\ Brazil \\ E-mail:nahas-renata@uol.com.br
}

How to cite this article: Cardili RN, Roselino AM. Elementary lesions in dermatological semiology: literature review. An Bras Dermatol. 2016;91(5):629-33. 